\section{Uptake of Atmospheric Water by the Hen Flea Ceratophyllus gallinae (Schrank)}

The only insects known to take up atmospheric wator actively aro 'T'enebrio larvae', Chortophaga nymphs', and the prepupae of the tropical rat flea Xenopsylla brasilien. $s i s^{3}$. The present observations add anothor example, the imago of the hen flea Ceratophyllus gallinae, and suggest a behavioural and ecological function for the phenomenon.

Imagines of $C$. gallinae, newly omerged from their cocoons and kept at 98 per cent relative humidity, did not lose weight as oxpected, but after $24 \mathrm{~h}$ had become heavier. This result was checked by following the daily woight changes of several groups of thirty nowly emerged fleas, at various relative humidities maintained by saturated salt solution and sodium hydroxide methods ${ }^{4}$. 'The temperature was $28^{\circ} \mathrm{C} \pm 1^{\circ} \mathrm{C}$. The graph (Fig. 1) shows that gain in weight is limited to the first day after emergence, and that an effect is discernible down to 82 per cent relative humidity.

Drinking cannot explain the increase in weight, because condensation did not occur on the fleas' containers. An active process is almost cortainly involved, for there are no known purely physical ways in which an insect can gain water from air at a rolative humidity as low as 82 per cent. The sudden failure of uptake on the socond day also sug. gests an active, rather than physical, mechanism.

The function of active uptake is probably related to the habit of the imago to remain quiescent within the cocoon during tho winter or in other periods when a host is not available. During this time loss of water must be reduced to a minimum, not only to provont doath directly from desiccation but also to enable the flea to omorgo officiontly from its cocoon. The bohavioural emergence mechanisms are dependent on a sufficient turgidity of the abdomen, which acts to anchor the flea while it tcars open the anterior polo of tho cocoon with its clypeal tubercle. Partially desiccated floas make all the correct emergence movements, but the loss of turgidity prevents tho tuberele pressing hard onough to tear the cocoon wall. These flcas eventually die within the eocoon. Such behavioural failure was observed on many nccasions both in the

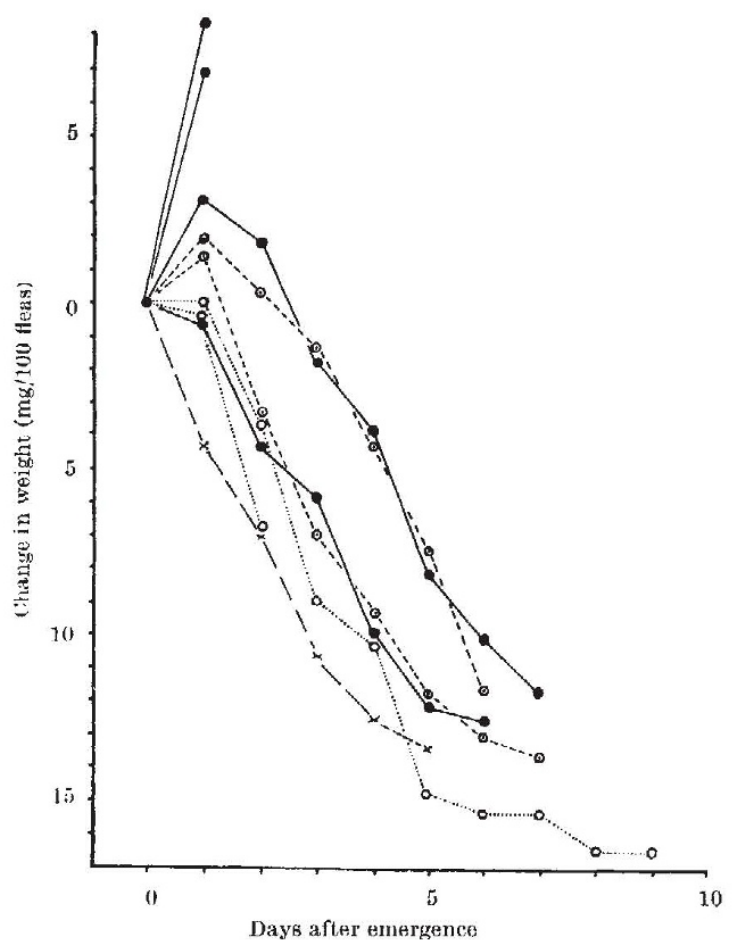

Fig. 1. Chamges in the weight of adult $C$. gallinae after emergence from

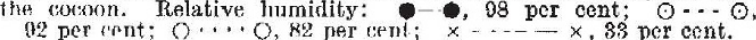

laboratory and in the field. Buxton ${ }^{5}$ notod a similar failure in Xenopsylla cheopis.

It is concluded that the mechanism of active uptake of water by the flea imago is probably largely concerned with opposing water loss during the cocooned rosting stage, so permitting the effective operation of emergence behaviour. This conclusion is consistent with the switching off of active uptake soon after emergence has occurred. The coconned imago forms the main resting stage of many flea species, including the plague vector Xenopsylla, and so it is quite possible that tho mochanism of active uptake and its relationship to emergence behaviour may be a widespread feature of flea ecology.

\section{A. HUMPHRIES}

Ethology Laboratory,

Uffeulme Clinic,

Queensbridge Road,

Birmingham 13.

${ }^{1}$ Mellanby, K., Proc. Roy. Soc., B, 111, 376 (1932).

${ }^{2}$ Judwig, D., Physiol. Zool., 10, 342 (1937).

${ }^{3}$ Edney, E. B., Bull, Entomol. Kex., 38, 263 (1947).

Madge, D. S., Lint. Exp. A ppl., 4, 143 (1961).

Buxton, l'. A., Parasitology, 39, 119 (1948).

\section{Effect of Coffee and Tea on Serum Lipids in the Rat}

WE report experiments designed to distinguish the effects of tho bevorage and of sugar on the blood lipids of rats. Epidemiological investigations ${ }^{1,2}$ have already shown an association between ischacmic hoart disease and the taking of coffee. Acute experiments in man and dogs $\mathrm{s}^{3,4}$ indicate that caffeine produces a rise in free fatty acids in the blood, but no chango in cholesterol or triglycerides. Our own investigations with paticnts ${ }^{5}$, howover, suggest that the association of heart disease with coffee (or tea) is more likely to be caused by the sugar taken with the coffeo or tea than by the caffeine they contain.

Male hooded rats weighing about $120 \mathrm{~g}$ were assigned to two main groups of twenty-cight. All were given purified dicts and water ad libitum; the dictary carbohydrate for one group was sucrose and for the other group was corr starch. Each of these main groups was divided into four sub-groups; one was given the control diot alone, the others had additions of coffee, or tea, or decaffoinated coffee. In an attompt to accentuate the possible effects of the supplements, an atherogenic diet was given: 25 per cent casein, 16 per cent hydrogenated coconut oil. 5 per cent mineral salts, 5 per cent cellulose powder, 1 por cent cholesterol, 1 per cent cholic acid, 47 per cent sucrose or corn starch. Because corn starch contains some corn oil, 0.56 por cent corn oil was added to the sucrose-containing diet.

The driod coffee was given at the rato of $2.3 \mathrm{~g}$ in $100 \mathrm{~g}$ of diet, and the dricd tea at the rate of $1.0 \mathrm{~g}$ in $100 \mathrm{~g}$ of diet. The average daily intake of caffeine was about. $22 \mathrm{mg}$ from ordinary coffee, $0.8 \mathrm{mg}$ from decaffeinated coffee and $12.5 \mathrm{mg}$ from tea. The coffee was preparcd according to a standard mothod ${ }^{6}$, and then freeze-dried. Tho tea was a commercially available preparation recommended to be mado up with $1.0 \mathrm{~g}$ of tea in a cup of $200 \mathrm{ml}$.

The amounts of tea or coffeo were equivalent to about twolvo cups a day for a $70 \mathrm{~kg}$ man, calculated for a $220 \mathrm{~g}$ rat (mean weight after 25 days on diet) from the formula metabolic weight $=$ wcight, , or to about fifty-four cups of coffoe or tea a day, calculated dircetly in proportion to body weight.

'The rats were killed after 50 days, after an overnight fast. Blood was taken directly from tho hoart for assay of cholestorol, phospholipids, and total esterificd acids ${ }^{7-9}$. Triglycerides were calculated by difference ${ }^{10}$.

The three groups receiving the tea or coffee showed a transitory holt in weight gain during the first 3 days, 